\title{
Thermodynamics and Kinetics of Adoption of Ag (I) on Paramagnetic Silica Rice Husk Ash Surface
}

\author{
Wardian Antoni, Saprini Hamdiani, Siti Raudhatul Kamali \\ ${ }^{2}$ Department of Chemistry, Faculty of Mathematic and Natural Science, University of Mataram, Indonesia \\ Email: saprini.h@unram.ac.id
}

Received october 01, 2018; Accepted February 13, 2019

\begin{abstract}
Synthesis of paramagnetic silica from rice husk ash has been carried out as an adsorbent for heavy metal $\mathrm{Ag}(\mathrm{I})$. This study tried to synthesis and characterized the thermodynamics and kinetics behaviour of paramagnetic silica from the husk ash as metal adsorbent $\mathrm{Ag}(\mathrm{I})$. Determination of optimal conditions for adsorption of metal ions $\mathrm{Ag}$ (I) is carried out by varying the $\mathrm{pH}$, concentration, and contact time of the adsorbent. The results showed that the optimum $\mathrm{pH}$ was at $\mathrm{pH} 3$, optimal concentration $\mathrm{Ag}(\mathrm{I})$ of $350 \mathrm{ppm}$ and optimal contact time of 90 minutes. At optimal conditions, paramagnetic silica adsorption capacity for metal ion Ag (I) is $323.62 \mathrm{mg} / \mathrm{g}$. The isotherm model that is suitable for paramagnetic silica is the Freundlich isotherm model. The kinetic model that is suitable for paramagnetic silica is the Pseudo Order 2 kinetic model.
\end{abstract}

Keywords: Rice husk ash, paramagnetic silica, adsorption, $\mathrm{Ag}(\mathrm{I})$

\section{PENDAHULUAN}

Perak terdapat di alam sebagai senyawa atau campuran dengan logam lain. Perak ditemukan sebagai senyawa dalam bentuk sulfida dan campuran bersama $\mathrm{Cu}, \mathrm{Au}, \mathrm{Pb}$, dan $\mathrm{Zn}$ [1-2]. Keberadaan perak biasanya bersamaan dengan emas. Ekstraksi emas berdasarkan hasil amalgamasi dengan konsentrasi $6-71 \mathrm{ppb}$ akan berasosiasi dengan perak $(\mathrm{Ag})$ pada konsentrasi 4 $47 \mathrm{ppb}$. Oleh karena itu industri pertambangan emas merupakan salah satu industri yang menyumbang limbah logam Ag. Limbah ini berasal dari air limbah yang tidak diolah terlebih dahulu terutama di pertambangan-pertambangan emas ilegal. Perak juga banyak dijumpai di dalam air limbah pelapisan logam, industri proses fotografi, dan proses film $X$ ray. Konsentrasi logam $\mathrm{Ag}$ di dalam air limbah pelapisan logam umumnya kurang dari $1 \mathrm{mg} / \mathrm{L}$, biasanya bergabung dengan senyawa kompleks sianida dan konsentrasi $\mathrm{Ag}$ di dalam air limbah industri fotografi umumnya lebih tinggi dari $1 \mathrm{mg} / \mathrm{L}$ [3-4].

Berbagai macam metode pengolahan limbah logam $\mathrm{Ag}(\mathrm{I})$ telah dilakukan, baik secara biologi, fisika dan kimia. Metode-metode yang pernah dilakukan diantaranya, reduksi logam berat Ag menggunakan metode presipitasi dan adsorpsi, pengolahan limbah cair logam berat melalui proses sedimentasi, mikrofiltrasi dan osmosis terbalik [5-6], biofiltrasi untuk air limbah domestik dan perbaikan kualitas air menggunakan koagulan alami [7-8]. Namun metode-metode di atas memiliki kekurangan, seperti metode filtrasi yang tidak mampu mengendapkan semua partikel yang tersuspensi, metode biofiltrasi yang sangat sensitif terhadap perubahan kondisi lingkungan sehingga belum bisa dimanfaatkan secara maksimal, serta metode koagulasi yang dapat menyebabkan polusi dan menyebabkan penyakit alzhaimer. Dari metodemetode tersebut, perlu dilakukan metode alternatif yang lebih efektif dan efisien untuk menyerap limbah cair logam berat serta tidak membahayakan lingkungan [9-10].

Metode yang efektif untuk pengolahan limbah logam berat adalah metode adsorpsi. Metode adsorpsi ini memiliki beberapa keuntungan antara lain, prosesnya sangat sederhana, biaya yang digunakan cukup murah dan, ramah lingkungan [11]. Salah satu adsorben yang mudah untuk dimodifikasi dan memiliki stabilitas kimia yang tinggi adalah silika gel. Silika merupakan padatan anorganik yang memiliki gugus silanol (ESi-OH) dan siloksan (ESi-O$\mathrm{Si} \equiv)$ yang efektif sebagai pengikat logam berat. Adsorpsi limbah logam berat menggunakan material silika pernah dilakukan oleh peneliti sebelumnya diantaranya, hibrida etilendiamino silika, dan silika mesopori monodispersi. Namun metode-metode tersebut menggunakan tetraetilortosilikat (TEOS) sebagai prekursor dalam sintesis silika gel. Prekursor TEOS beracun sehingga tidak ramah lingkungan dan harganya mahal [12-16]. Oleh karena itu perlu dicari bahan alternaif lain yang lebih murah dan ramah terhadap lingkungan.

Salah satu bahan organik yang dapat digunakan sebagai prekursor sintesis silika gel 
adalah sekam padi. Secara kimia, abu sekam padi mempunyai kandungan $\mathrm{SiO}_{2}$ 89,47-98 \% [17]. Tingginya kandungan silika, dan kelimpahannya yang besar membuat abu sekam padi berpotensi besar sebagai sumber silika [18].

Selain adanya gugus silanol ( $(\equiv \mathrm{Si}-\mathrm{OH})$ dan siloksan (=Si-O-Si $\equiv$ ), kemampuan adsorpsi silika gel dapat ditingkatkan dengan memberi sifat magnetik dengan penambahan $\mathrm{Fe}_{3} \mathrm{O}_{4}$. Adsorben yang memiliki sifat magnetik baru-baru ini mendapat banyak perhatian dalam pengaplikasiannya untuk mengurangi ion logam berat dari air limbah [19]. Kemampuan menyerap $\mathrm{Fe}_{3} \mathrm{O}_{4}$ berdasarkan sifat senyawa tersebut sebagai paramagnetik dengan gaya magnet yang dihasilkannya dan merupakan oksida besi yang memiliki energi permukaan yang tinggi sehingga mampu mengikat logam. Nuryono dkk [19] mengadsorpsi multilogam Au(III), Cu(II) dan, $\mathrm{Ni}$ (II) dengan menggunakan magnetit yang dilapisi silika. Namun, kemampuan silika paramagnetik belum pernah dilakukan terhadap logam $\mathrm{Ag}$ [20-21].

Berdasarkan uraian tersebut, maka penelitian mengenai sintesis silika paramagnetik dari abu sekam padi sebagai adsorben logam berat $\mathrm{Ag}(\mathrm{I})$ penting untuk dilakukan. Penambahan material magnetit pada adsorben bertujuan agar sifat paramagnetik yang dimiliki oleh magnetit dapat mengefektifkan penyerapan logam [19]. Material $\mathrm{Fe}_{3} \mathrm{O}_{4}$ yang telah dilapisi dengan silika tersebut kemudian dikarakterisasi dengan FTIR dan XRD dan diaplikasikan untuk mempelajari sifat adsorpsi pada limbah logam berat $\mathrm{Ag}(\mathrm{I})$. Dengan adanya silika paramagnetik ini, diharapkan pencemaran limbah logam $\mathrm{Ag}(\mathrm{I})$ dapat direduksi.

\section{METODE PENELITIAN}

\section{Bahan Penelitian}

Bahan kimia yang digunakan dalam penelitian ini antara lain : Sekam padi, akuades (Laboratorium Kimia), $\mathrm{NaOH} 4 \mathrm{M}$ (Nitra Kimia), $\mathrm{HCl}$ 3M (Nitra Kimia), NaOH 1M teknis (Laboratorium Kimia Dasar), HCl 1M (Laboratorium Kimia), besi (III) oksida $\left(\mathrm{Fe}_{3} \mathrm{O}_{4}\right) /$ magnetit (Sigma Aldrich), larutan buffer sitrat pH 6 p.a., padatan $\mathrm{AgNO}_{3}$ (Laboratorium Kimia), kertas indikator $\mathrm{pH}$ universal, kertas saring dan kertas saring Whattman no. 42.

\section{Alat Penelitian}

Dalam penelitian ini digunakan peralatan analisis dan peralatan penunjang sebagai berikut: Spektrofotometer Serapan Atom (SSA) (Shimadzu AA 7000), Difraktometer sinar-X (Shimadzu 6000), dan Spektrofotometer Infra Merah (Shimadzu FTIR8201 PC), ayakan ukuran 104 mikron, Sonikator (S
$300 \mathrm{H}$ ), pengaduk magnet, oven (Fischer Scienific), timbangan analtik (Shimadzu AUX 320), tungku pemanas, cawan porselin, alat penggerus (Lumping 40 dan mortar), pompa vakum, peralatan gelas dan peralatan plastik.

\section{Prosedur Penelitian \\ Uji Kapasitas Adsorpsi Silika Paramagnetik Analisis Kadar Logam Ag(I) Menggunakan SSA}

Analisis dilakukan dengan membuat kurva kalibrasi terlebih dahulu kemudian diukur kadar logam dengan menggunakan Spektofotometer Serapan Atom (SSA). Kurva kalibrasi dibuat dengan mencari hubungan antara konsentrasi larutan standar terhadap absorbansi, sehingga diperoleh persamaan linear sesuai dengan persamaan 3.1.

$$
y=b x+a
$$

Keterangan :

$y=$ Absorbansi; $x=$ Konsentrasi larutan standar; $a=$ Intersep (titik potong garis dengan sumbu y); $b=$ Slope (Kemiringan garis)

\section{Penentuan Kondisi Optimum Adsorpsi Optimasi $\mathrm{pH}$ adsorpsi}

Sebanyak $10 \mathrm{~mL}$ larutan ion logam $\mathrm{Ag}(\mathrm{I})$ dengan konsentrasi 100 ppm dimasukkan ke dalam gelas kimia. Larutan tersebut kemudian diatur pHnya menjadi $\mathrm{pH} 1,2,3,4,5$ dan, 6 dengan penambahan buffer sitrat, $\mathrm{HCl} 1 \mathrm{M}$ dan $\mathrm{NaOH} 1 \mathrm{M}$ untuk mendapat $\mathrm{pH}$ yang diinginkan. Adsorben sebanyak 0,01 gram dimasukkan ke dalam masing-masing larutan dan dikocok selama 60 menit. Kemudian campuran disaring dan filtrat dari campuran tersebut diukur konsentrasi ion logamnya menggunakan SSA. Konsentrasi ion logam yang sudah dianalisi menggunakan SSA dapat dihitung melalui persamaan 3.2 (Kurniawati dkk., 2013).

$$
Q=\frac{\left(C_{0}-C_{e}\right)}{m} \times V
$$

Keterangan:

$Q=$ Konsentrasi ion logam yang terserap $(\mathrm{mg} / \mathrm{g}) ; \mathrm{V}=$ Volume larutan $(\mathrm{L}) ; \mathrm{m}=$ Massa adsorben $(\mathrm{g})$

$\mathrm{Co}=$ Konsentrasi awal ion logam (ppm); Ce = Konsentrasi akhir ion logam (ppm)

Optimasi Konsentrasi dan kapasitas adsorpsi ion logam $\mathrm{Ag}(\mathrm{I})$

Sebanyak $10 \mathrm{~mL}$ larutan ion logam $\mathrm{Ag}(\mathrm{I})$ dengan konsentrasi 50, 100, 150, 200, 250, 300, 350 dan 400 ppm dimasukkan ke dalam gelas Erlenmeyer. Pada larutan tersebut kemudian diatur $\mathrm{pH}$ larutannya menjadi $\mathrm{pH}$ optimum dengan penambahan buffer sitrat, serta $\mathrm{HCl} 1 \mathrm{M}$ dan $\mathrm{NaOH}$ 
1M. Adsorben sebanyak $0,01 \mathrm{~g}$ dimasukkan ke dalam masing-masing larutan dan dikocok selama 60 menit. Setelah itu campuran disaring dan filtrat dari campuran tersebut diukur konsentrasi ion logamnya menggunakan SSA untuk mengetahui nilai $Q$ seperti pada persamaan 3.2.

\section{Optimasi waktu kontak adsorpsi}

Sebanyak $10 \mathrm{~mL}$ larutan ion logam $\mathrm{Ag}(\mathrm{I})$ pada konsentrasi optimum dimasukkan ke dalam gelas Erlenmeyer. Pada larutan tersebut kemudian diatur $\mathrm{pH}$ larutannya menjadi $\mathrm{pH}$ optimum adsorpsi dengan penambahan buffer sitrat, serta $\mathrm{HCl} 1 \mathrm{M}$ dan $\mathrm{NaOH}$ 0,1M. Adsorben sebanyak 0,01 g dimasukkan ke dalam masing-masing larutan dan dikocok selama 0, 30, 60, 90, 120 dan 150 menit. Setelah itu campuran disaring dan filtrat dari campuran tersebut diukur konsentrasi ion logamnya menggunakan Spektrofotometer SSA untuk mengetahui nilai $Q$ seperti pada persamaan 3.2.

\section{HASIL DAN PEMBAHASAN}

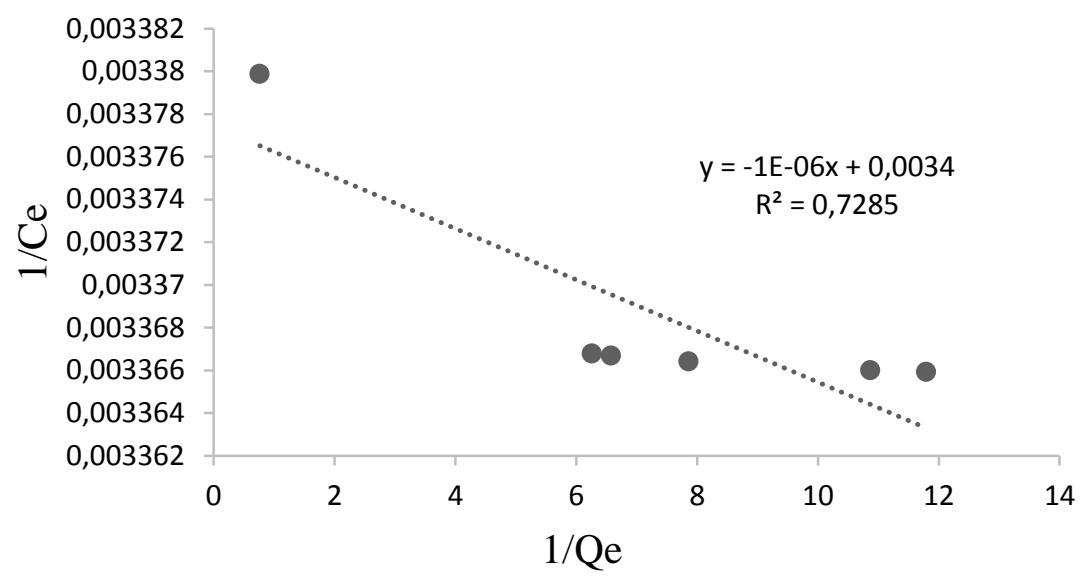

Gambar1. Kurva isoterm langmuir dari silika paramagnetik

Persamaan isoterm adsorpsi Langmuir dapat diturunkan secara teoritis dengan asumsi telah terjadi kesetimbangan antara molekul-molekul zat yang diadsorpsi pada permukaan adsorben dengan molekul-molekul zat yang tidak teradsorpsi (Day and Underwood, 2002). Kurva model Isoterm Adsorpsi dibuat berdasarkan persamaan 2.2 kemudian membuat grafik hubungan antara 1/Q dan 1/Ce. Berdasarkan gambar tersebut diperoleh persamaan linear yaitu $y=b x+a$, dimana y merupakan $1 / Q e$ dan $x$ merupakan $1 / \mathrm{Ce}$. Nilai slope (b) akan bernilai sama dengan log ks.

Model Isoterm Freundlich mengasumsikan bahwa terdapat lebih dari satu lapisan adsorbat

\section{Isoterm Adsorpsi}

Keadaan kesetimbangan adsorpsi ion logam dengan menggunakan adsorben silika parmagnetik dapat dinyatakan secara matematis dengan isoterm adsorpsi. Ada beberapa model yang dapat digunakan untuk menggambarkan data-data percobaan isoterm adsorpsi, namun pada penelitian ini menggunakan dua model persamaan yaitu persamaan Langmuir dan Freundlich. Hal ini dikarenakan kedua persamaan tersebut sesuai untuk menjelaskan proses adsorpsi logam dalam larutan (media air). Kurva model Isoterm Langmuir dan Freundlich yang dihasilkan pada pengadsorpsian ion logam $\mathrm{Ag}(\mathrm{I})$ dengan menggunakan adsorben silika paramagnetik diperlihatkan pada Gambar 1 dan 2.

Isoterm adsorpsi Langmuir didasarkan atas beberapa asumsi, yaitu (a) adsorpsi hanya terjadi pada lapisan tunggal (monolayer), (b) panas adsorpsi tidak tergantung pada penutupan permukaan, serta (c) semua situs dan permukaannya bersifat homogen. 


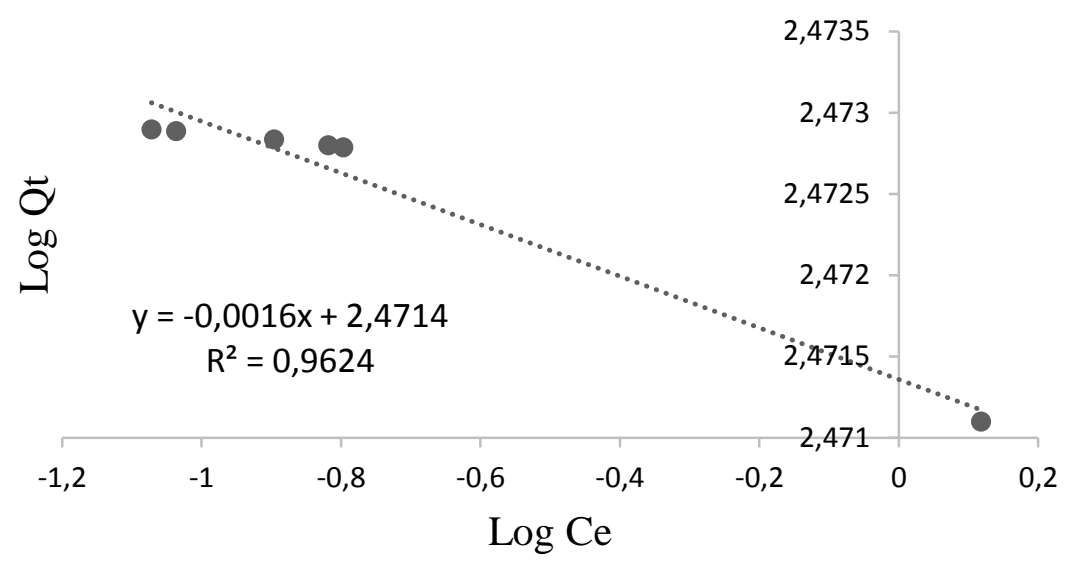

Gambar 2. Kurva isoterm freundlich dari silika paramagnetik

Tabel 1. Nilai $R^{2}$ Isoterm Freundlich dan Languir

\begin{tabular}{cc}
\hline Model Isoterm & Nilai $\mathrm{R}^{2}$ \\
\hline Langmuir & 0,73 \\
Freundlich & 0,96 \\
\hline
\end{tabular}

Berdasarkan nilai $\mathrm{R}^{2}$ pada kedua kurva tersebut terlihat bahwa model Isoterm Freundlich menunjukkan kesesuaian yang lebih baik dibandingkan model Isoterm Langmuir. Model Isoterm Freundlich berasumsi bahwa energi adsorpsi tergantung pada interaksi adsorbat dengan permukaan adsorben yang bersifat heterogen. Heterogenitas permukaan adsorben dapat menyebabkan interaksi antara situs aktif satu dan yang lain pada permukaan adsorben dengan molekul adsorbat juga berbeda sehingga permukaan adsorbat yang terikat pada permukaan adsorben dapat membentuk lebih dari satu lapisan (multilayer). Penelitian terdahulu dilakukan oleh Nuryono [20] dan mampu mengadsorpsi logam $\mathrm{Ag}(\mathrm{I})$ hingga $90 \%$ dengan adsorben silika termodifikasi gugus. Mekanisme pengikatan adsorbat oleh silika paramagnetik dimungkinkan karena gugus silanol

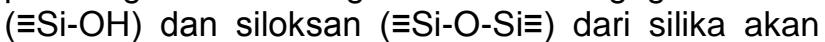
berinteraksi dengan kompleks logam yang terlarut dalam air. Salah satu kelebihan dari $\mathrm{Fe}_{3} \mathrm{O}_{4}$ adalah memiliki sifat paramagnetik, sehingga selain dapat mengadsorpsi ion logam melalui ikatan koordinasi maupun ionik, zat ini juga mampu mengadsorpsi melalui kemagnetan yang dimilikinya.

\section{Kinetika Adsorpsi}

Penentuan mekanisme dan laju adsorpsi dapat ditentukan dengan pendekatan model kinetika. Salah satu tujuan utama penelitian kinetika adsorpsi adalah untuk menentukan model yang cocok pada kinetika adsorpsi ion logam $\mathrm{Ag}(\mathrm{I})$ dan untuk mendapatkan nilai-nilai parameter kinetika adsorpsi. Kinetika adsorpsi ion logam $\mathrm{Ag}(\mathrm{I})$ oleh adsorben silika paramagnetik ditentukan dengan mengolah data hasil adsorpsi pada pengaruh waktu kontak terhadap nilai kapasitas adsorpsi.

Nilai-nilai parameter kinetika adsorpsi dapat ditentukan dengan membuat suatu grafik model kinetika adsorpsi. Penentuan model kinetika orde 1 dibuat berdasarkan persamaan pada Tabel 3 dengan membuat grafik hubungan In Ce lawan $\mathrm{t}$ seperti pada Gambar 3. Gambar 3 menunjukkan merupakan kurva model kinetika orde I untuk adsorpsi $\mathrm{Ag}(\mathrm{I})$ oleh adsorben silika paramagnetik. Berdasarkan gambar tersebut diperoleh persamaan linear yaitu $y=-0,0389 x-0,0415$ dengan $R^{2}=0,82$. Nilai $k$ untuk kinetika orde 1 sama dengan negatif nilai slope, dari persamaan tersebut dapat diketahui nilai $\mathrm{k}$ sebesar 0,039 menit $^{-1}$.

Penentuan model kinetika orde 2 dibuat berdasarkan persamaan pada Tabel 2 yaitu dengan membuat grafik hubungan $1 /$ Ce lawan t seperti pada Gambar 3. Gambar tersebut merupakan kurva model kinetika orde 2 untuk adsorpsi $\mathrm{Ag}(\mathrm{I})$ oleh adsorben silika paramagnetik dengan $\mathrm{y}=0,1183+$ 1,411 dan nilai $R^{2}=0,91$. Nilai $k$ untuk model kinetika orde 2 sama dengan nilai slope yang diperoleh pada kurva. Berdasarkan persamaan linear tersebut dapat diketahui nilai $\mathrm{k}$ sebesar 0,11 menit $^{-1}$.

Penentuan model kinetika pseudo orde 1 dilakukan dengan membuat grafik hubungan log $(Q-$ Qt) lawan t seperti pada Gambar 3. Berdasarkan gambar tersebut diperoleh persamaan linear yaitu y $=-0,0244 x-0,0722$ dengan nilai $R^{2}$ sebesar 0,87 . Nilai $k$ untuk model kinetika pseudo orde 1 setara dengan nilai negatif slope dikalikan 2,30. Dari persamaan tersebut dapat diketahui nilai $k$ sebesar 0,06 menit $^{-1}$. Penentuan model kinetika pseudo orde 2 ditentukan berdasarkan persamaan pada Tabel 2. 
Berdasarkan persamaan tersebut dapat dibuat grafik

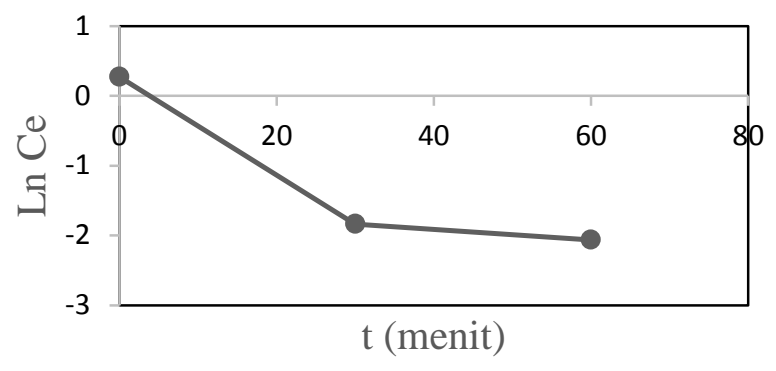

Kurva model kinetika orde 1

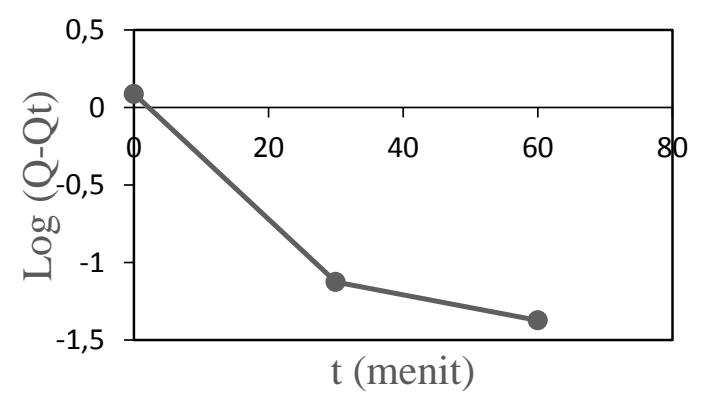

Kurva model kinetika pseudo orde 1 hubungan t/Qt lawan t seperti pada Gambar 3.

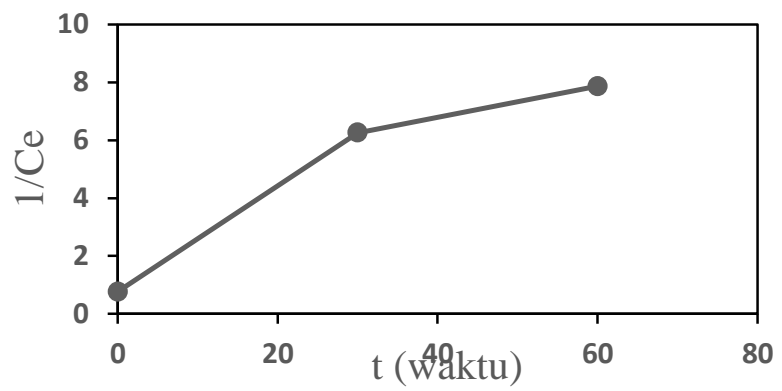

Kurva model kinetika orde 2

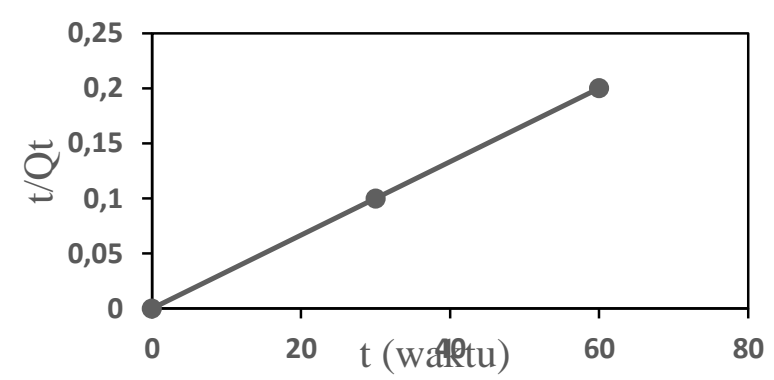

Kurva model pseudo orde 2

Gambar 3. Kurve model Kinetika Adsopsi

Pada gambar tersebut diperoleh persamaan linear yaitu $y=0,0033 x+0,000004$ dengan nilai $R^{2}=$ 1. Nilai $k$ diperoleh dari $\frac{1}{\text { intersep }}$ yang dikalikan dengan nilai kuadrat slope. Dari persamaan linear tersebut dapat diketahui nilai k sebesar 2,72 g. $\mathrm{mg}^{-1} \cdot \mathrm{menit}^{-1}$.

Hasil analisis model kinetika terhadap pengaruh waktu kontak adsorpsi ion logam $\mathrm{Ag}(\mathrm{I})$ dengan menggunakan adsorben silika paramagnetik disajikan pada Tabel 2.

Tabel 2. Data model kinetika adsorpsi

\begin{tabular}{lcc}
\hline Model Kinetika & $\begin{array}{c}\text { Nilai Linearitas } \\
\left(\mathrm{R}^{2}\right)\end{array}$ & $\mathrm{k}\left(\right.$ menit $\left.^{-1}\right)$ \\
\hline Orde 1 & 0,82 & $3,89 \times 10^{-2}$ \\
Orde 2 & 0,91 & $1,18 \times 10^{-2}$ \\
Pseudo Orde 1 & 0,87 & $5,62 \times 10^{-2}$ \\
Pseudo Orde 2 & 1 & $272,25 \mathrm{x}$ \\
& & $10^{-2}$ \\
\hline
\end{tabular}

Data dalam Tabel 2 menunjukkan bahwa adsorpsi ion logam $\mathrm{Ag}(\mathrm{I})$ oleh adsorben yang digunakan paling cocok mengikuti model reaksi pseudo orde 2 yang ditandai dengan nilai $R^{2}$ paling besar yaitu 1 dengan nilai konstanta laju $(\mathrm{k})=2,72 \mathrm{gr}^{\mathrm{mg}}{ }^{-1} \mathrm{menit}^{-1}$. Kinetika adsorpsi pseudo orde 2 menggambarkan adsorpsi terjadi secara kimia melalui berbagai mekanisme seperti interaksi elektrostatik dan pembentukan kompleks. Adsorpsi secara kimia melibatkan ikatan kovalen koordinasi sebagai hasil penggunaan bersama pasangan elektron oleh adsorben dan adsorbat (ion logam). Hal ini dimungkinkan karena nilai keelektronegatifan dari atom $\mathrm{O}$ pada gugus

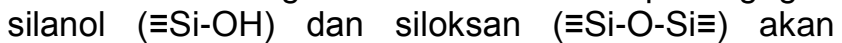
berpotensi berikatan kovalen dengan ion logam sehingga proses adsorpsi secara kimia dapat berlangsung. Hasil ini juga sesuai dengan penelian sebelumnya yang dilakukan oleh Nuryono [19] bahwa pengadsorpsian ion logam menggunakan adsorbsen silika paramagnetik mengikuti model kinetika pseudo orde 2

\section{KESIMPULAN}

Model interaksi antara ion logam $\mathrm{Ag}(\mathrm{I})$ dengan silika paramagnetik mengikuti model isoterm adsorpsi Freundlich yang menunjukkan bahwa interaksi antara ion logam $\mathrm{Ag}(\mathrm{I})$ dan silika paramagnetik membentuk lapisan multilayer dan model kinetika Pseudo orde 2 yang menunjukkan bahwa interaksi antara adsorben dan adsorbat terjadi melalui interaksi secara elektrostatik dan pembentukan kompleks.

\section{DAFTAR PUSTAKA}

[1] Hettiarachchi, S. R., Schaefer, B. K., Yson, R. L., Staples, R. J., Herbst-Irmer, R., \& Patterson, H. H. (2007). Observation of a mixed-metal transition in heterobimetallic $\mathrm{Au} / \mathrm{Ag}$ dicyanide systems. Inorganic chemistry, 46(17), 6997-7004. 
[2] Benoit, G., Oktay-Marshall, S. D., Cantu li, A., Hood, E. M., Coleman, C. H., Corapcioglu, M. O., \& Santschi, P. H. (1994). Partitioning of $\mathrm{Cu}$, $\mathrm{Pb}, \mathrm{Ag}, \mathrm{Zn}, \mathrm{Fe}, \mathrm{Al}$, and $\mathrm{Mn}$ between filterretained particles, colloids, and solution in six Texas estuaries. Marine Chemistry, 45(4), 307336.

[3] Jones, L. H., \& Penneman, R. A. (1954). Infrared absorption studies of aqueous complex ions: I. Cyanide complexes of $\mathrm{Ag}$ (I) and $\mathrm{Au}(\mathrm{I})$ in aqueous solution and adsorbed on anion resin. The Journal of Chemical Physics, 22(6), 965-970.

[4] Myagkaya, I. N., Lazareva, E. V., Gustaytis, M. A., \& Zhmodik, S. M. (2016). Gold and silver in a system of sulfide tailings. Part 2: reprecipitation on natural peat. Journal of Geochemical Exploration, 165, 8-22.

[5] de Freitas, E. D., da Silva, T. L., da Silva, M. G. C., \& Vieira, M. G. A. (2018). Adsorption and Recovery of Silver from Aqueous Solutions. Silver Recovery From Assorted Spent Sources: Toxicology Of Silver lons, 55.

[6] Cânda, L. R., \& Ardelean, E. (2017, January). Preliminary experimental research for silver recovery from radiographic films. In IOP Conference Series: Materials Science and Engineering (Vol. 163, No. 1, p. 012024). IOP Publishing.

[7] Folens, K., Huysman, S., Van Hulle, S., \& Du Laing, G. (2017). Chemical and economic optimization of the coagulation-flocculation process for silver removal and recovery from industrial wastewater. Separation and Purification Technology, 179, 145-151.

[8] Qi, F., Yang, B., Wang, Y., Mao, R., \& Zhao, X. (2017). H2O2 assisted photoelectrocatalytic oxidation of $\mathrm{Ag}$-Cyanide complexes at metalfree $\mathrm{g}-\mathrm{C} 3 \mathrm{~N} 4$ photoanode with simultaneous $\mathrm{Ag}$ recovery. Acs Sustainable Chemistry \& Engineering, 5(6), 5001-5007.

[9] Szilva, J., Kuncová, G., Patzák, M., \& Dostálek, P. (1998). The application of a solgel technique to preparation of a heavy metal biosorbent from yeast cells. Journal of sol-gel science and technology, 13(1-3), 289-294.

[10] Jadhav, U. U., \& Hocheng, H. (2012). A review of recovery of metals from industrial waste. Journal of Achievements in Materials and Manufacturing Engineering, 54(2), 159167.

[11] Aguado, J., Arsuaga, J. M., Arencibia, A., Lindo, M., \& Gascón, V. (2009). Aqueous heavy metals removal by adsorption on aminefunctionalized mesoporous silica. Journal of hazardous materials, 163(1), 213-221.
[12] Repo, E., Warchoł, J. K., Bhatnagar, A., \& Sillanpää, M. (2011). Heavy metals adsorption by novel EDTA-modified chitosan-silica hybrid materials. Journal of colloid and interface science, 358(1), 261-267.

[13] Mercier, L., \& Pinnavaia, T. J. (1998). Heavy metal ion adsorbents formed by the grafting of a thiol functionality to mesoporous silica molecular sieves: factors affecting $\mathrm{Hg}$ (II) uptake. Environmental Science \& Technology, 32(18), 2749-2754.

[14] Singh, V., Singh, S. K., Pandey, S., \& Kumar, P. (2011). Sol-gel synthesis and characterization of adsorbent and photoluminescent nanocomposites of starch and silica. Journal of Non-Crystalline Solids, 357(1), 194-201.

[15] Kalantari, S., Yousefpour, M., \& Taherian, Z. (2017). Synthesis of mesoporous silica/iron oxide nanocomposites and application of optimum sample as adsorbent in removal of heavy metals. Rare Metals, 36(12), 942-950.

[16] Hamdiani, S., Nuryono, N., \& Rusdiarso, B. (2015). KINETIKA ADSORPSI ION EMAS (III) OLEH HIBRIDA MERKAPTO SILIKA. Jurnal Pijar Mipa, 10(1).

[17] HAMDIANI, S. (2010). Adsorpsi-desorpsi dan selektifitas hibrida merkapto silika terhadap ion emas (III) dalam sistem multilogam $\mathrm{Au}-\mathrm{Cu}$, $\mathrm{Au}$ $\mathrm{Ni}$ dan $\mathrm{Au}-\mathrm{Cu}-\mathrm{Ni}$ (Doctoral dissertation, Universitas Gadjah Mada).

[18] Nuryono, N., Muliaty, E., Rusdiarso, B., SAKTI, S. C. W., \& Tanaka, S. (2014). Adsorption of $\mathrm{Au}$ (III), $\mathrm{Cu}$ (II) and Ni (II) on Magnetite Coated with Mercapto Groups Modified Rice Hull Ash Silica. 日本イオン交換学会誌, 25(4), 114-121.

[19] Amaria, A., Suyanta, S., \& Nuryono, N. (2017). Coating of L-Arginine Modified Silica on Magnetite through Two Different Sol-Gel Routes. Indonesian Journal of Chemistry, 17(2), 256-263.

[20] Miftiyati, S., Hamdiani, S., \& Darmayanti, M. (2018). Synthesis Of Paramagnetic Merkapto Silica Hybrid From Rice Husk Ash For $\mathrm{Ag}(\mathrm{I})$ Adsorben. Acta Chimica Asiana, 1(2), 30-36.

[21] Azmiyawati, C., Pratiwi, P. I., \& Darmawan, A. (2018, April). New Silica Magnetite Sorbent: The Influence of Variations of Sodium Silicate Concentrations on Silica Magnetite Character. In IOP Conference Series: Materials Science and Engineering (Vol. 349, No. 1, p. 012012). IOP Publishing. 